\title{
Innovative Organization within Local Government: An Innovation Class
}

\author{
Sharon Salvador \\ Department of Political Science at the University of the Philippines Diliman, Philippines \\ Received: August 3, 2020 \\ Received in Revised: August 11, 2020 \\ Accepted: August 13, 2020
}

\begin{abstract}
Innovation is often identified with the use of new methods by profit organizations to obtain the effectiveness and efficiency of both products, services and, methods in dealing with business competition. Innovative actions carried out by government organizations seem to be symptomatic. This is marked by the rise of superior programs and services run by the government, both physical and policy. How to Implement and Challenge the Computer Assisted Test (CAT. To Understand Computer Assisted Test. The results of the implementation the CAT system development process, namely: (a) building an organizational knowledge base, (b) designing an innovation system, and (c) building a system sustainability Efforts that have been made in building system sustainability are among others by procuring CAT functions and maintaining the work domain.
\end{abstract}

Keywords: Innovation, Local Government, Computer Assisted Test

\section{Introduction}

Innovation is one aspect of bureaucratic culture that greatly influences the success of bureaucratic reform. However, innovation has not become the main part of bureaucratic culture in Indonesia. Innovation in the world of government will be difficult if there are still many employees who are not motivated to change. Forming an innovative government is still not optimal considering the awareness to always innovate still leaves room for improvement, even though innovation is very important to be carried out at every level of government in order to achieve "good governance" (Héritier, 1997).

According to Government Regulation, regional innovation aims to improve the performance of local government administration, and is directed at accelerating the realization of community welfare. The bureaucratic reform program that has occurred in Indonesia has been rolling since the passing of Law concerning Local Government. The law reads: regional autonomy is the right, authority and obligation of an autonomous region to manage and regulate its own government affairs and interests of its people in accordance with the prevailing laws and regulations. It is hoped that the enactment of this law can spur the government to make improvements towards good governance. This has had a major effect on the development of the nation's life, especially in the bureaucracy.

Innovation is often identified with the use of new methods by profit organizations to obtain the effectiveness and efficiency of both products, services, and methods in dealing with business competition. Innovative actions carried out by government organizations seem to be symptomatic. This is marked by the rise of superior programs and services run by the government, both physical and policy. Over time, reality shows that government organizations are starting to move more flexibly and keep up with changes that occur in the environment. Change is inevitable in the midst of the development of the organizational environment, both internal and external. The only way that an organization can take is by 
doing innovation. innovation is an idea or behaviour that provides new things to the organization.

\section{Understanding Innovation In Government Organizations}

Government organizational innovation is a process of creating, developing, and implementing new ideas that can provide better benefits such as reducing costs, increasing efficiency, and service effectiveness (Borins, 2009).

One way to develop good governance is to increase creativity and innovation in government, starting at the individual level, moving up to groups, and then leading to organizational innovation. The goal is that all parties in the workplace can develop skills that can make it easier to do each job.

Regional innovation has been regulated in Government Regulation which guarantees that every government agency can carry out various forms of reform in every implementation of the regional government so that it can support the achievement of the good governance process.

According to Government Regulation, regional innovation aims to improve the performance of local government administration and is directed at accelerating the realization of community welfare. The bureaucratic reform program that has occurred in Indonesia has been rolling since the passing of Law concerning Local Government. The law reads: regional autonomy is the right, authority, and obligation of an autonomous region to manage and regulate its government affairs and interests of its people following the prevailing laws and regulations. It is hoped that the enactment of this law can spur the government to make improvements towards good governance. This has had a major effect on the development of the nation's life, especially in the bureaucracy.

One of the driving factors for the emergence of innovative actions in government organizations is the changing demands for improved service quality from the external environment and stakeholders and is also driven by policies implemented by the central government through the program agenda for the acceleration of bureaucratic reform. One of the agendas of this bureaucratic reform is carried out through the "public service innovation" program.

\section{Computer Assisted Test (CAT)}

Efforts to implement innovation by government organizations are carried out by the National Civil Service Agency in managing the Computer Assisted Test (CAT)-based employee selection process. According to National Civil Service Agency, what is meant by the meaning of CAT (Computer Assisted Test) is a selection method with computer aids used to obtain a minimum standard of basic competence for applicants. Civil Servant basic competency standards are needed to realize civil servant professionalism, and CAT is believed to be able to guarantee Civil Servant basic competency standards in Basic Competency Test.

The Test is designed to reduce, eliminate, or prevent the practice of Corruption, Collusion, and Nepotism in the employee selection process. CAT presents transparency through a computer-based selection scenario. The creation of the CAT system is a strategy of changing the way and working mechanism based on the use of information technology to improve the quality of work. The form of CAT system innovation is closer to total innovation, which is the use of new service methods tailored to the level of customer needs.

The CAT system innovation process is a form of total and process innovation because it presents a new mechanism for an objective, transparent, and accountable employee 
recruitment system as a strategy in responding to the challenges of the needs expected by the community (Scott \& Pandey, 2000).

Three main dimensions in the CAT system development process, namely:

1) Building an organizational knowledge base

The emergence of CAT innovation ideas cannot be separated from the organizational learning process (learning orientation) of government agency knowledge sources, namely from academic papers, benchmarking activities, and problems in the work environment. efforts to build an organizational knowledge base are also carried out by adjusting the needs of stakeholders (customer orientation). This is related to problems that occur in the work environment, especially in response to community demands regarding a transparent and quality employee recruitment process.

The problems that exist in the implementation of employee recruitment are identified with the Corruption, Collusion, and Nepotism action which encourages government agency innovation agents to look for alternatives. As a follow-up step from the discovery of CAT system innovation ideas, steps were taken to design an innovation system as a pre-program implementation stage. Designing an innovation system is carried out through three scenarios, namely collaborating.

2) Designing an innovation system

As a follow-up step to finding the CAT system innovation idea, steps are taken to design an innovation system as a pre-program implementation stage. Designing an innovation system is carried out through three scenarios, namely collaborating, designing work mechanisms, and striving for product legality.

3) Build system sustainability

Building a sustainable system is intended to ensure the existence of the CAT system to continue amid a consolidated bureaucratic environment. Building the sustainability of the system is done to obtain policy and program authorization as important things in every implementation of the activities of government organizations.

\section{CAT Case Study}

The Computer Assisted Test (CAT) -based Basic Competency Selection Test was conducted last year at the implementation of the Civil Servant test in the city of Makassar, namely at the government media Building. This is an example of activities that have used the CAT (Computer Assisted Test) system, which is very helpful because the CAT system immediately processes the results of the tests carried out and doesn't have to wait long to find out the results because it has been processed on the computer of each test taker. For this reason, CAT is the right innovation to provide convenience in carrying out government activities.

\section{CAT Innovation Challenges}

In its implementation, the CAT system innovation process cannot be avoided by the obstacle factor. In general, CAT obstacles are in the form of technical barriers, constraints on management resources, and obstacles in the context of institutional relationships. One of the main obstacles to the innovation process is related to the lack of resources for potential employees and the lack of regulations that support the innovation climate (De Graaff \& Cowdroy, 1997; Seng Tan, 1995; Gijselaers, 1995). 
In general, the obstacles to implementing the CAT system are related to technical constraints as well as constraints on management resources through the strategy used. This is evident from the implementation of the CAT system facilitation process which has continued until now. On the other hand, obstacles related to institutional relationships are still a challenge for the CAT system. Several policies and ideal designs of the CAT system have not been realized due to unsuccessful harmonization efforts not only from within government agency but also from other institutions that have a linkage of functions and authorities.

Facing challenges in institutional relations is not always synonymous with a confrontation with other institutions. This strategy must be implemented appropriately without encouraging the birth of a competitive situation that affects the implementation of the next innovation agenda.

\section{Technical Barriers To The CAT Innovation Process}

The centralized policy on the one hand guarantees a professional system implementation but indirectly also hinders the implementation process. Also, the existence of a database of test questions which is not the full responsibility of government agency is a barrier in itself. Many requests for test facilitation are not accommodated due to the absence of test questions. Other technical obstacles related to the implementation of the test, such as failed login participants, the computer hangs, missing scores, and the presence of test jockeys. (Bodin, 2020)

\section{Management Resource Constraints}

A common problem faced by government organizations is the lack of resources for potential employees. Even though the quantity is large, in reality, it is difficult to support the work of the organization. The age gap for employees has implications for the lack of availability of the number of potential employees according to job requirements. (Donnelly \& Donnelly, 1990; Terwangne, 2017)

\section{Conclusion}

Organizations must give birth to government innovations to facilitate and expedite all activities related to governance, this greatly affects the survival of the community. Three main dimensions in the CAT system development process are: (a) building an organizational knowledge base, (b) designing an innovation system, and (c) building system sustainability. Efforts that have been made in building system sustainability are among others by procuring CAT functions and maintaining the work domain. In this context, efforts to penetrate government agency need to be supported by sharpening government agency branding as a national personnel management organization.

\section{References}

Bodin, Ö., Robins, G., McAllister, R. R., Guerrero, A. M., Crona, B., Tengö, M., \& Lubell, M. (2016). Theorizing benefits and constraints in collaborative environmental governance: a transdisciplinary social-ecological network approach for empirical investigations. Ecology and Society, 21(1).

Borins, S. F. (Ed.). (2009). Innovations in government: Research, recognition, and replication. Brookings Institution Press.

De Graaff, E., \& Cowdroy, R. (1997). Theory and practice of educational innovation through introduction of problem-based learning in architecture. International Journal of Engineering Education, 13(3), 166-174.

Donnelly, D. D., \& Donnelly, N. J. (1990). U.S. Patent No. 4,973,086. Washington, DC: U.S. Patent and Trademark Office. 
Gijselaers, W. (1995). Educational Innovation in Economics and Business Administration:: The Case of Problem-Based Learning (Vol. 1). Springer Science \& Business Media.

Héritier, A. (1997). Policy-making by subterfuge: interest accommodation, innovation and substitute democratic legitimation in Europe-perspectives from distinctive policy areas. Journal of European Public Policy, 4(2), 171-189.

Maroye, L., Van Hooland, S., Celorrio, F. A., Soyez, S., Losdyck, B., Vanreck, O., \& de Terwangne, C. (2017). Managing electronic records across organizational boundaries. Records Management Journal.

Scott, P. G., \& Pandey, S. K. (2000). The influence of red tape on bureaucratic behavior: An experimental simulation. Journal of Policy Analysis and Management, 19(4), 615633.

Seng Tan*, O. (2004). Students' experiences in problem-based learning: three blind mice episode or educational innovation?. Innovations in Education and Teaching International, 41(2), 169-184. 